\title{
Online psychoeducation in the COVID-19 pandemic situation: an effort to improve mental health
}

\section{Psikoedukasi daring dalam situasi pandemi COVID-19: sebuah usaha peningkatan kesehatan mental}

\author{
Edilburga Wulan Saptandari, Zafira Rahmania Nur Shabarina, Acintya Ratna Priwati \\ Fakultas Psikologi, Universitas Gadjah Mada \\ Jl. Sosio Humaniora Bulaksumur, Sleman, Daerah Istimewa Yogyakarta 55281, Indonesia
}

\begin{abstract}
ARTICLE INFO:
ABSTRACT

Received: 2019-05-24 Revised: 2019-10-19

Accepted: 2020-01-18

The pandemic situation that occurs often has a psychological impact on the people who experience it. This community service program aims to provide psychoeducation to the public regarding the psychological impacts that may be felt due to the COVID-19 situation. The program is carried out online in the form of UKP Bersinergi UKP Berbagi through WhatsApp, Live Instagram, and Zoom Meeting lectures. This program was held four times in April - October 2020. The keynote speakers in this program are psychologists, while the participants are educational personnel at UGM for Whatsapp lectures and public for Live Instagram and Zoom Meeting. Based on the evaluation given after the event, the UKP Bersinergi UKP Berbagi program is considered effective in providing psychoeducation for participants. This can be seen from the positive response submitted through the evaluation form. In addition, the results of a satisfaction survey related to the UKP Bersinergi UKP Berbagi program during the COVID-19 pandemic showed that most of the participants were satisfied with the services

Keywords:

COVID-19; online services; psychoeducation provided.
\end{abstract}

(C) 2022 Abdimas: Jurnal Pengabdian Masyarakat Universitas Merdeka Malang This is an open access article distributed under the CC BY-SA 4.0 license (https://creativecommons.org/licenses/by-sa/4.0/)

How to cite: Saptandari, E. W., Shabarina, Z. R. N., \& Priwati, A. R. (2021). Online psychoeducation in the COVID-19 pandemic situation: an effort to improve mental health. Abdimas: Jurnal Pengabdian Masyarakat Universitas Merdeka Malang, 7(1), 38-53. https://doi.org/10.26905/abdimas.v7i1.6348

\section{PENDAHULUAN}

Pada akhir tahun 2019, wabah virus corona (COVID-19) mulai merebak di Kota Wuhan, China dan kemudian menyebar ke berbagai penjuru dunia dalam waktu yang cukup singkat. Diketahui sudah lebih dari 200 negara terjangkit COVID-19 (Kementerian Kesehatan Republik Indonesia, 2020). Wabah tersebut dinyatakan oleh World Health Organization (WHO) sebagai krisis kesehatan masyarakat berskala Internasional pada 30 Januari 2020 (World Health Organization, 2020). Penyakit COVID-19 ini kemudian menjadi perhatian secara global dan merupakan wabah pneumonia atipikal terbesar sejak wabah sindrom pernapasan akut berat (SARS-CoV) pada tahun 2003 (Wang, et al., 2020). Kemudian, pada 11 Maret 2020 World Health Organization (WHO) menyatakan COVID-19 sebagai pandemi seiring bertambahnya 


\section{Online psychoeducation in the COVID-19 pandemic situation: an effort to improve mental health}

Edilburga Wulan Saptandari, Zafira Rahmania Nur Shabarina, Acintya Ratna Priwati

kasus positif terinfeksi dan tingkat kematian yang meningkat secara signifikan di seluruh dunia (Carver \& Phillips, 2020). Hal tersebut membuat seluruh dunia menghadapi ancaman kesehatan secara global dan perlu melakukan deteksi dini untuk membatasi jumlah orang yang terinfeksi mengingat meluasnya penyebaran virus dan kasus positif terus meningkat.

Menurut laporan WHO (2020), pada 12 Februari 2020, sebanyak 45.171 kasus positif tercatat secara global. Kemudian, dilaporkan sebanyak 40.788 kasus positif baru secara global tercatat pada 23 Maret 2020 dengan total 332.930 orang dan 14.509 orang diantaranya meninggal dunia. Peningkatan kasus COVID-19 ini terjadi secara signifikan karena terdapat lebih dari 10 negara atau daerah yang tercatat telah terjangkit COVID-19 sejak 15 Februari 2020 (World Health Organization, 2020). Pada 18 April 2020 sudah terdapat 2.160.207 kasus positif COVID-19 secara global dan sebanyak 146.088 diantaranya dilaporkan meninggal dunia (World Health Organization, 2020). Hingga 19 April 2020, tercatat sebanyak 6.575 kasus positif COVID-19 di Indonesia (Kementerian Kesehatan Republik Indonesia, 2020). Kasus ini pun diperkirakan akan terus meningkat mengingat penyebaran virus relatif mudah tersalurkan.

Pemerintah Republik Indonesia melalui Badan Nasional Penanganan Bencana (BNPB) telah mengeluarkan protokol dalam menangani kondisi pandemi yang terjadi dengan mengimbau masyarakat untuk selalu menerapkan perilaku hidup bersih dan sehat (PHBS) serta menghindari kegiatan di luar rumah dengan menjaga jarak fisik dengan orang lain (physical distancing) dan tetap tinggal di rumah (Gugus Tugas Percepatan Penanganan COVID-19, 2020). Pembatasan sosial dan jaga jarak fisik pun dilaksanakan dalam skala besar sesuai dengan Peraturan Pemerintah Nomor 21 Tahun 2020 tentang Pembatasan Sosial Berskala Besar dalam Rangka Percepatan Penanganan Corona Virus Disease 2019 (COVID-19) berdasarkan ketentuan UU Nomor 6 Tahun 2018 tentang Kekarantinaan Kesehatan. Kebijakan ini sesuai dengan keputusan Presiden Negara Republik Indonesia, Joko Widodo, melalui Keppres Nomor 11 Tahun 2020 tentang Penetapan Kedaruratan Kesehatan Masyarakat Corona Virus Disease 2019 (COVID-19).

Kondisi ini menimbulkan berbagai dampak pada masyarakat di seluruh dunia, khususnya di Indonesia. Indonesia merupakan negara dengan populasi terbesar ke-4 di dunia sehingga memiliki risiko tinggi terkena penyebaran COVID-19 yang lebih luas. Demi mencegah risiko yang mungkin terjadi, pemerintah memberlakukan berbagai kebijakan. Tentunya kebijakan tersebut memberikan dampak yang beragam pada berbagai sektor mulai dari bidang kesehatan, ekonomi, sosial, politik, pendidikan, dan sebagainya. Akibat keterbatasan aktivitas sosial, berbagai kondisi individu juga dialami, terutama kondisi psikologis. Konsekuensi protokol penanganan dan perawatan selama epidemi, seperti isolasi atau karantina dapat memberikan efek pada kesehatan mental (Srivatsa \& Stewart, 2020). Karantina dapat menjadi tekanan bagi sebagian banyak orang, terutama bagi mereka yang merasa cemas dengan keselamatan mereka atau marah karena merasa "dikurung" (Taylor, 2019). Masalah utama yang dihadapi akibat pandemi COVID-19, yaitu kecemasan dan perasaan tidak berdaya karena kurangnya dukungan emosional (Wang Y., et al., 2020). Kondisi kesehatan mental yang terganggu dapat memengaruhi wellbeing seseorang (Kang, et al., 2020).

Para pekerja medis yang menangani kasus-kasus tersebut tentunya menghadapi tekanan yang besar karena berisiko tinggi terinfeksi, bekerja dengan ekstra, mengalami kelelahan, diskriminasi, dan sulit berhubungan sosial dengan orang lain. Kondisi tersebut dapat mempengaruhi dan mengganggu kesehatan mental. Saat epidemi SARS-CoV merebak di Singapura pada tahun 2003, dilaporkan para pekerja medis mengalami gejala gangguan psikis, seperti burnout, stres pasca trauma (PTSD), kecemasan, dan gejala depresi bahkan berlanjut setelah wabah tersebut usai (Chan \& Huak, 2014). Kondisi yang sama juga terjadi pada sebagian besar staff Unit Gawat Darurat dan bangsal Psikiatri saat epidemi SARS-CoV menyebar di Taiwan pada tahun 2003 (Torales, O'Higgins, Castaldelli-Maia, \& Ventriglio, 2020). Selain itu, saat wabah MERS-CoV merebak di Korea dan menginfeksi lebih dari 100 orang pada tahun 2015, para pekerja medis dilaporkan mengalami gangguan stres pasca trauma (PTSD) bahkan semakin meningkat 
ABDIMAS: Jurnal Pengabdian Masyarakat Universitas Merdeka Malang

Volume 7, No 1, February 2022: 38-53

setelah selesai masa karantina (Lee et al., 2018). Tidak hanya saat epidemi virus corona, pada tahun 2014 saat epidemi Ebola meluas di Afrika bagian Barat, prevalensi yang mengalami gangguan psikologis dilaporkan sangat tinggi dan berlangsung cukup lama (Srivatsa \& Stewart, 2020).

Selain petugas medis, masyarakat yang juga menaati protokol penanganan dan perawatan selama epidemi dengan mengisolasi diri dapat mengalami kondisi yang serupa. Pandemi COVID-19 dapat memicu rasa takut, cemas, perasaan tidak berdaya, stigma, dan perasaan negatif lainnya (Wang, et al., 2020). Individu yang cenderung cemas terinfeksi, biasanya akan melakukan berbagai cara untuk melindungi diri mereka dan menghindari berbagai hal yang berhubungan dengan penyakit tersebut (Taylor, 2019). Selama masa pandemi COVID-19, internet merupakan sumber informasi utama masyarakat. Menurut Torales et al. (2020), seseorang yang sering menggunakan ponsel untuk mengakses info terkini melalui media sosial selama masa lockdown lebih berisiko mengalami stres. Penelitian yang dilakukan pada masyarakat yang tidak terinfeksi saat epidemi SARS-CoV, diketahui usia yang lebih muda berhubungan dengan peningkatan self-blame (Wang, et al., 2020). Depresi dan rasa duka yang mendalam juga dirasakan oleh mereka yang kehilangan orang tersayang dalam kondisi pandemi (Taylor, 2019).

Sejak pertengahan bulan Maret 2020, wabah COVID-19 mulai merebak secara meluas. Hal ini mendorong munculnya pembatasan maksimal di tempat kerja dan di sekolah/kuliah dikarenakan adanya himbauan untuk pembatasan fisik (physical distancing). Tindak lanjut dari kebijakan tersebut adalah munculnya kebijakan untuk bekerja dari rumah (work from home) dan mengikuti kuliah/sekolah dari rumah masing-masing (school from home). Hal ini membuat situasi dan cara kerja yang berbeda dibanding sebelumnya. Segala sesuatu yang bisa dikerjakan di kantor dan di bangku kuliah/sekolah berubah menjadi di rumah, dan dilakukan via daring. Perubahan itu terjadi sangat cepat sehingga memaksa dan menuntut semua orang di segala penjuru tanah air untuk beradaptasi. Proses yang terjadi selama perubahan ini tentunya bukanlah suatu hal yang mudah dilakukan. Mulai dari penyesuaian diri dengan situasi kerja di kantor dengan di rumah, harus belajar hal baru agar tetap bekerja secara produktif meskipun dilakukan secara daring, harus pandai dalam mengatur waktu agar dapat bekerja secara profesional sekaligus menciptakan situasi yang harmonis di dalam keluarga, hingga mengatasi rasa bosan yang muncul selama masa pembatasan fisik.

Memahami respons kesehatan mental terkait kondisi kedaruratan kesehatan masyarakat mengenai COVID-19 dapat membantu masyarakat mempersiapkan aksi tanggap bencana secara luas. Intervensi psikologis dalam kondisi krisis dapat menjadi alternatif dalam mengurangi tekanan psikologis yang disebabkan oleh kondisi pandemi serta meningkatkan stabilitas sosial (Wang Y., et al., 2020). Menanggapi situasi yang sedang terjadi, hotline bantuan psikologis perlu diberlakukan secara luas untuk menyediakan dukungan psikologis, konseling psikologis, intervensi kedaruratan, dan layanan lainnya oleh tenaga ahli kesehatan mental kepada masyarakat selama kondisi pandemi (Wang Y., et al., 2020). Selain itu, psikoedukasi kepada masyarakat mengenai pandemi COVID-19, dampak pandemi, dan solusi yang dapat dilakukan juga perlu untuk diberikan. Pelayanan ini dimaksudkan sebagai bentuk pertolongan pertama psikologis untuk membantu mencegah dan mengurangi tekanan psikologis masyarakat yang disebabkan oleh pandemi. Penggunaan internet dan smartphone semakin membantu penyebaran informasi dan sumber daya dalam mendukung bantuan psikologis.

Berdasarkan penjelasan di atas, dapat disimpulkan bahwa peningkatan layanan psikologis sangat dibutuhkan, khususnya ketika menjalani work from home dan school from home selama masa pandemi. Pandemi COVID-19 ini tidak hanya berdampak pada kondisi mental individu sendiri, namun juga ke lingkungan, mulai dari yang terkecil yaitu keluarga, dan yang lebih besar lagi adalah lingkungan sosial, diantaranya kaitannya dengan lingkungan di sekolah bagi anak-anak (ketika menjalani school from home), dan lingkungan kerja bagi orangtua (ketika menjalani work from home). Oleh karena itu, rancangan program untuk memberikan dukungan psikologis selama masa pandemi disusun untuk 
memfasilitasi hal tersebut. Agar tema yang disasar saling berkaitan menjadi suatu program psikoedukasi yang menyeluruh, maka program layanan psikologis dibuat secara serial/berkesinambungan, serta diseleranggarakan secara daring untuk mengurangi risiko penyebaran virus. Peneliti juga ingin melihat lebih jauh mengenai media yang sesuai untuk psikoedukasi berbasis daring. Oleh karena itu, program pelayanan psikologis secara daring tersebut akan dilaksanakan oleh Unit Konsultasi Psikologi Universitas Gadjah Mada melalui tiga bentuk, yaitu Kuliah Whatsapp (melalui tulisan dan audio), Live Instagram UKP UGM, dan Webinar melalui Zoom Cloud Meeting (tatap muka melalui video).

Program ini diberikan judul UKP Bersinergi UKP Berbagi (UBUB) dan akan dilaksanakan sebanyak empat sesi dengan tema-tema yang relevan dengan kondisi saat itu, seperti working-life balance, mengenali diri serta mengurangi emosi negatif (cemas, takut, insecure, dII) dan stres akademik. UBUB akan diselenggarakan selama bulan April - Oktober 2020. Sasaran program juga dibuat secara bertahap dengan melihat urgensi kebutuhan, dimulai dari lingkungan terdekat yaitu tenaga kependidikan di lingkungan UGM, lalu dilanjutkan ke psikoedukasi yang ditujukan untuk masyarakat umum. Program psikoedukasi berbasis daring ini merupakan suatu bentuk pengabdian masyarakat yang bertujuan untuk memberikan layanan psikologis kepada masyarakat, sehingga mampu membantu meningkatkan kesehatan mental, meningkatkan resiliensi psikologis, dan mengurangi tekanan psikologis akibat pandemi COVID-19.

\section{METODE}

\section{Tujuan Kegiatan}

Kegiatan yang selanjutnya disebut UKP Bersinergi UKP Berbagi (UBUB) ini bertujuan untuk memberikan psikoedukasi kepada masyarakat secara daring, sehingga partisipan lebih terampil dalam menghadapi berbagai isu yang muncul dikarenakan situasi COVID-19. Konten yang dibahas dalam UBUB ini merupakan isu-isu yang relevan dengan keseharian partisipan dan dipandang dapat mengganggu kesehatan psikologis selama masa pandemi COVID-19.

\section{Partisipan Penelitian}

Partisipan dalam kegiatan ini berasal dari berbagai kalangan, baik mahasiswa, tenaga kependidikan Universitas Gadjah Mada, dan masyarakat umum yang mendaftar acara UBUB yang diinformasikan secara terbuka melalui media sosial (Whatsapp grup dan Instagram). UBUB ini terbagi menjadi empat kegiatan yang dilangsungkan sejak bulan April hingga Oktober 2020. Keseluruhan partisipan yang terdaftar dalam kegiatan UBUB ini sejumlah 266 orang (235 perempuan, 31 laki-laki). Sebanyak 127 orang dari total partisipan bersedia untuk mengisi kuesioner yang diberikan. Dari seluruh responden tersebut, 27,56\% responden berada pada rentang usia remaja (15-20 tahun), 65,35\% responden memasuki usia dewasa awal (21-40 tahun), dan 7,09\% merupakan responden yang berada masa dewasa akhir (di atas 40 tahun).

\section{Bentuk Kegiatan}

Kegiatan UBUB ini disajikan dengan tiga macam bentuk kegiatan yang berbeda dengan menghadirkan narasumber dan moderator yang mendalami bidang tema yang dikupas tuntas, yaitu (1) webinar melalui tulisan dan audio yang dikemas dalam bentuk Kuliah Whatsapp untuk UBUB ke-1, (2) diskusi dan sharing melalui live instagram untuk UBUB ke-2, serta (3) webinar tatap muka melalui video Zoom Cloud Meeting untuk UBUB ke-3 dan UBUB ke-4.

Berdasarkan rumusan masalah yang sudah dijabarkan sebelumnya, tema yang diangkat dalam kegiatan UBUB ini adalah isu-isu yang dekat dengan keseharian masyarakat selama menjalani masa 
ABDIMAS: Jurnal Pengabdian Masyarakat Universitas Merdeka Malang

Volume 7, No 1, February 2022: 38-53

pandemi COVID-19, dan perlu mendapatkan dukungan psikologis. Rincian kegiatan tersebut adalah sebagai berikut:

\section{UBUB ke-1, webinar melalui kuliah WhatsApp, dengan judul “Work from Home dan Harmoni} Keluarga" pada hari Jumat, 3 April 2020

Pada awal masa pandemi COVID-19 di Indonesia, langkah awal untuk memutus penyebaran COVID-19, pemerintah memberlakukan physical distancing, melalui aturan bekerja dari rumah (work from home) dan sekolah dari rumah (school from home). Sebulan menjalani perubahan, isu utama yang paling dirasakan masyarakat saat beradaptasi dengan perubahan, adalah tentang bekerja dari rumah, terutama dalam menyeimbangkan kebutuhan untuk bekerja secara produktif namun tetap menjaga keharmonisan interaksi di dalam keluarga.

Melalui webinar ini peserta diajak untuk mengurai peran-peran kehidupan yang dirasa kurang selaras dijalankan selama pandemi COVID-19, kemudian diajak menyadari dan menemukan solusi untuk menyeimbangkan peran sebagai pekerja dan peran sebagai bagian dari keluarga ketika bekerja dari rumah pada hari kerja. Informasi mengenai kuliah WhatsApp ini disampaikan melalui poster yang dibagikan ke media sosial, seperti yang tertera dalam Gambar 1.

\section{UBUB ke-2, diskusi dan sharing melalui live instagram, dengan judul “Berdamai dengan Perasaan Insecure, Kecemasan, dan Kejenuhan selama Masa Pandemi" pada hari Jumat, 15 Mei 2020.}

Tiga bulan pasca pandemi COVID-19 merebak di Indonesia, dampak dan perubahan hidup yang besar mulai disertai dengan ketidakpastian kapan berakhirnya masa tersebut. Akibatnya, tema kecemasan dan insecurity menjadi isu utama yang mengancam kesehatan mental sebagian besar masyarakat di berbagai kalangan. Di samping munculnya rasa insecure, adanya pembatasan sosial yang mengharuskan untuk SFH dan WFH secara berkepanjangan pun mulai mendorong individu merasa jenuh. Berangkat dari permasalahan ini, tema dukungan psikologis selanjutnya yang diangkat adalah berdamai dengan perasaan insecure, kecemasan dan kejenuhan selama masa pandemi. Publikasi dilakukan melalui media sosial seperti yang ditunjukkan dalam Gambar 2.
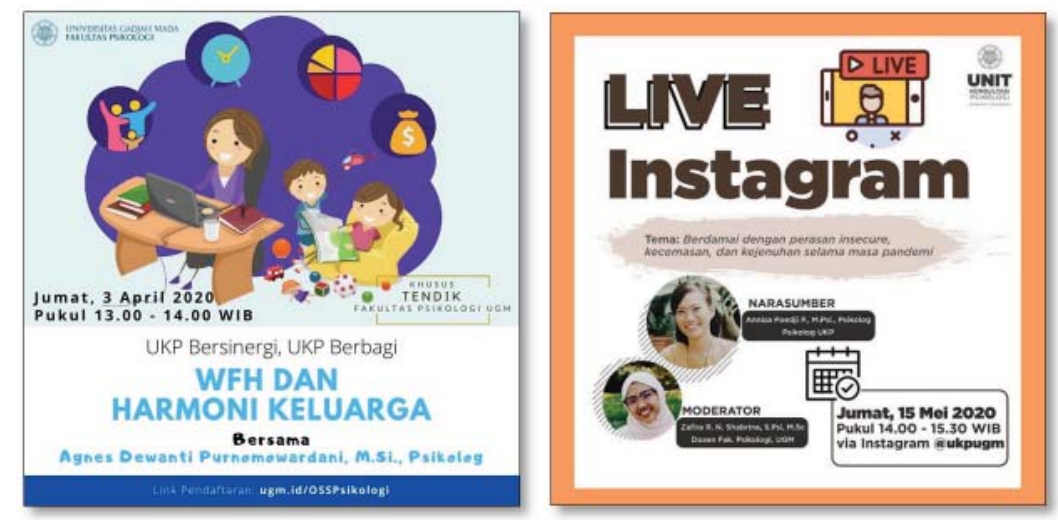

Gambar 1. Poster Publikasi UKP Bersinergi UKP Berbagi 1

Gambar 2. Poster Publikasi untuk UKP Bersinergi UKP Berbagi

Melalui webinar UBUB ke-2 ini, peserta yang terdampak COVID-19 diajak untuk mengelola rasa, mengelola pikiran, dan mengelola informasi agar menurunkan rasa cemas dan insecure. Ketika peserta 
berhasil mengelola ketiganya, peserta juga diajak untuk berdamai dengan rasa jenuh selama WFH atau SFH melalui aktivitas-aktivitas positif yang bersifat terapeutik agar membangun suasana yang lebih semangat, produktif, dan meningkatkan kesehatan mental peserta.

\section{UBUB ke-3, webinar melalui zoom cloud meeting, dengan judul "Reparenting Self: My Self, My Comfort Zone (Berdamai dengan Emosi Negatif selama Situasi New Normal)" pada hari Jumat,}

\section{Juli 2020}

Enam bulan memasuki masa pandemi COVID-19, muncullah situasi new normal, yaitu perubahan perilaku untuk tetap menjalankan aktivitas normal namun dengan protokol kesehatan yang ketat. Tatanan dan budaya baru yang terbentuk pun berdampak pada perubahan pola kerja, ekonomi, pola perilaku, pola relasi, fisik dan emosi. Umumnya, ketika individu menghadapi tekanan, akan memiliki berbagai alternatif untuk release tension. Akan tetapi, situasi pandemi COVID-19 di era new normal ini "memaksa" individu untuk kembali berada dalam situasi yang tidak nyaman (menjalankan semua aktivitas dengan banyak aturan dan pembatasan yang ketat). Informasi-informasi tentang kritik, teguran untuk menaati protokol kesehatan yang terus-menerus, himbauan yang diabaikan, hingga konflik kebijakan selama pandemi ini yang membuat lelah mental pun tak terhindarkan lagi. Di sisi lain, situasi tersebut mengharuskan individu untuk bertahan dalam ketidaknyamanan tersebut dan bertemu setiap sisi dirinya yang mungkin dihindari. Akibatnya, situasi ini memicu munculnya luka batin pada inner child seseorang ketika mengalami pembatasan ("dikekang oleh berbagai aturan") selama proses pengasuhan.

Emosi negatif yang muncul karena adanya trigger selama masa pandemi ini akan berdampak pada menurunnya kesehatan mental individu. Oleh karena itu, individu membutuhkan proses berdamai dengan emosi positif tersebut melalui reparenting self, yaitu proses mengasuh diri sendiri dengan memenuhi kebutuhan yang tidak didapatkan di masa kecil. Melalui proses ini peserta diajak untuk menyadari pola relasi dengan orangtua, dampaknya pada diri saat kecil, kemudian dampaknya pada pola diri di masa sekarang (menyadari pikiran, emosi, dan perilaku yang menyertainya). Setelah mampu mengidentifikasi, peserta diajak untuk berdamai dengan diri sendiri melalui proses menerima, merefleksikan, meregulasi emosi, dan membangun emosi saat ini untuk melakukan reparenting (memenuhi kebutuhannya di masa kecil, dan mengapresiasi keseluruhan proses yang dilaluinya). Kegiatan UBUB 3 ini juga dipublikasikan melalui media sosial menggunakan poster seperti yang ditunjukkan pada Gambar 3.

UBUB ke-4, webinar melalui Zoom Cloud Meeting, dengan judul “Unlock Your Potential: Menjadi Mahasiswa Tangguh \& Bebas Stres Akademik", pada hari Jumat, 23 Oktober 2020.

Penambahan kasus terkonfirmasi positif COVID-19 di bulan Oktober 2020, mendorong untuk diberlakukannya pembatasan mobilitas (PSBB), salah satunya dengan menyelenggarakan school from home (SFH). Perubahan ini tidak hanya berdampak pada pembelajaran daring, namun seluruh aktivitas akademik pun dialihkan ke daring, termasuk ujian, magang, praktikum, dan wisuda secara daring. Studi kasus di lapangan selama UKP membuka layanan konsultasi secara daring selama masa pandemi COVID19, menunjukkan bahwa mahasiswa cenderung rentan mengalami stres akademik. Hal ini dikarenakan mahasiswa berada dalam usia "emerging adult" yang rentang mengalami distres psikologis. Tantangan baru dan perubahan yang sulit dijalani juga turut meningkatkan distres psikologis pada mahasiswa selama menjalani perannya di masa pandemi COVID-19. Tantangan akademik tidak hanya proses pembelajaran dan aktivitas kuliahnya yang berbasis daring, namun di setiap aktivitas tersebut mahasiswa diharuskan lebih terampil dalam penggunaan teknologi dan bagaimana membuat aktivitas belajar menjadi lebih menarik. Beberapa mahasiswa yang sedang menjalani penelitian, praktik kerja lapangan, dan penulisan tugas akhir pun mengalami distres psikologis selama masa pembatasan sosial ini. 
ABDIMAS: Jurnal Pengabdian Masyarakat Universitas Merdeka Malang

Volume 7, No 1, February 2022: 38-53

Melalui UBUB ke-4 ini peserta diajak untuk mengenali dan memahami diri sendiri agar dapat membuka potensi untuk bertahan menghadapi tantangan era pandemi COVID-19. Kemampuan untuk mengenali dan memahami potensi diri ini akan memudahkan mahasiswa untuk membangun model atau gaya belajar yang sesuai kebutuhannya, yang mengintegrasikan kebutuhan pribadi sebagai manusia dengan peran penggunaan teknologi, serta menemukan solusi yang efektif untuk meraih impiannya. Peserta juga diajak untuk mengelola stres akademik dengan cara mengenali kapasitas dan kemampuan diri, menyadari situasi sulit tidak selamanya, kemudian memilah hal-hal yang bisa dikendalikan dan hal-hal yang tidak dapat dikendalikan, menguatkan kondisi psikologis pribadi melalui kegiatan selfcare (merawat diri) dan fokus pada optimalisasi potensi. Informasi mengenai acara UBUB ini dibagikan kepada masyarakat umum melalui sosial media, dengan poster seperti yang tertera pada Gambar 4.
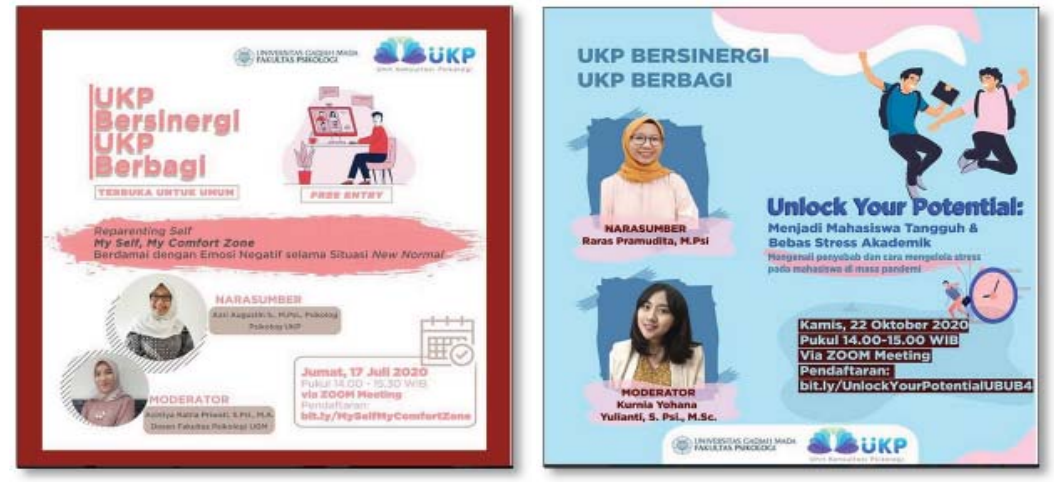

Gambar 3. Poster Kegiatan UKP Bersinergi UKP Berbagi 3

Gambar 4. Poster Kegiatan UKP Bersinergi UKP Berbagi 4

Metode yang digunakan dalam kegiatan ini adalah action research. Metode ini dipilih karena dapat menguji efektivitas, menemukan, menciptakan, dan mengembangkan tindakan baru sehingga saat tindakan tersebut diterapkan dalam bidang yang disasar akan memudahkan proses pelaksanaan dan menghasilkan output yang lebih berkualitas.

Efektivitas kegiatan dapat dilihat dari lembar evaluasi yang diisi oleh partisipan. Lembar evaluasi tersebut mengukur tingkat kepuasan dan evaluasi hasil kegiatan (meliputi harapan, kesan, capaian, dan saran).

\section{HASIL DAN PEMBAHASAN}

Situasi pandemi COVID-19 yang penuh dengan ketidakpastian mendorong individu untuk mencari bantuan atau dukungan psikologis. Kebutuhan tersebut semakin meningkat seiring dengan berkembangnya isu kesehatan mental akibat terdampak COVID-19. Pelaksanaan psikoedukasi secara daring melalui media sosial menjadi langkah nyata untuk mewujudkan masyarakat yang sadar akan kesehatan mental. Penelitian sebelumnya telah menemukan keterkaitan antara media sosial dengan kesehatan mental (Berryman et al., 2018). Meskipun, penggunaan media sosial secara umum mungkin tidak menimbulkan adanya dampak signifikan pada kesehatan mental. Namun, selama pandemi COVID-19 ini banyak informasi yang belum tentu kebenarannya, berita palsu hingga informasi negatif (berkaitan dengan duka cita) yang bertebaran di media sosial (Lai et al., 2020). Hal ini lah yang dapat meningkatkan kecemasan dan menimbulkan kebingungan dari masyarakatyang kemudian berujung pada permasalahan kesehatan mental. Lebih lanjut, penyebaran informasi yang belum tentu kebenarannya 
merupakan penyebab yang paling besar dampaknya pada isu kesehatan mental (Hammad \& Alqarni, 2021). Maka dari itu, dibutuhkan platform yang dapat memberikan informasi akurat bagi masyarakat. Melihat urgensi dari kebutuhan tersebut, UKP kemudian membuat layanan UKP Bersinergi UKP Berbagi (UBUB) yang bertujuan sebagai layanan psikoedukasi kesehatan mental yang akurat dan mudah dijangkau oleh masyarakat. Layanan ini telah selesai dilakukan melalui media Whatsapp, Zoom dan Instagram pada bulan April hingga Oktober 2020 lalu, dengan melibatkan sebanyak 266 partisipan.

Pada layanan UBUB ini, pemilihan topik bahasan didasarkan pada permasalahan yang ditemukan pada layanan konsultasi gratis UKP. Selain mempertimbangkan hal tersebut, tema UBUB yang dipilih di setiap serialnya diselaraskan dengan konteks yang sedang dialami oleh sebagian besar sasaran program. Pemilihan berdasarkan kedua pertimbangan ini ditemukan lebih efektif dalam menyasar dan memfasilitasi kebutuhan masyarakat, terutama dalam mewujudkan program pengabdian masyarakat. Efektivitas ini ditunjukkan dengan adanya respon positif partisipan pasca mengikuti psikoedukasi, minimal mendapatkan dukungan psikologis dan insight. Tema UBUB ke-1 dipilih tema tentang keseimbangan bekerja dari rumah dengan harmoni keluarga, karena tema ini paling dominan muncul di awal-awal pandemi, tidak hanya berkaitan erat dengan perubahan ekonomi, tetapi juga menjadi permasalahan yang berdampak besar dalam kehidupan individu. Individu diharuskan beradaptasi dan menyeimbangkan diri dalam menjalankan peran-perannya secara bersamaan, baik sebagai individu maupun sebagai bagian dari sosial, dalam hal ini kaitannya dengan relasi kerja dan relasi di dalam keluarga. Pengelolaan dan batasan waktu yang jelas antara bekerja dan beraktivitas bersama keluarga menjadi salah satu kunci keseimbangan bekerja dari rumah (Crosbie \& Moore, 2004). Melalui kegiatan ini, efektivitas pemilihan topik dari psikoedukasi dan dukungan psikologis yang diberikan, terlihat ketika peserta mampu menemukan solusi untuk menyeimbangkan peran sebagai pekerja dan peran sebagai bagian dari keluarga ketika bekerja dari rumah pada hari kerja.
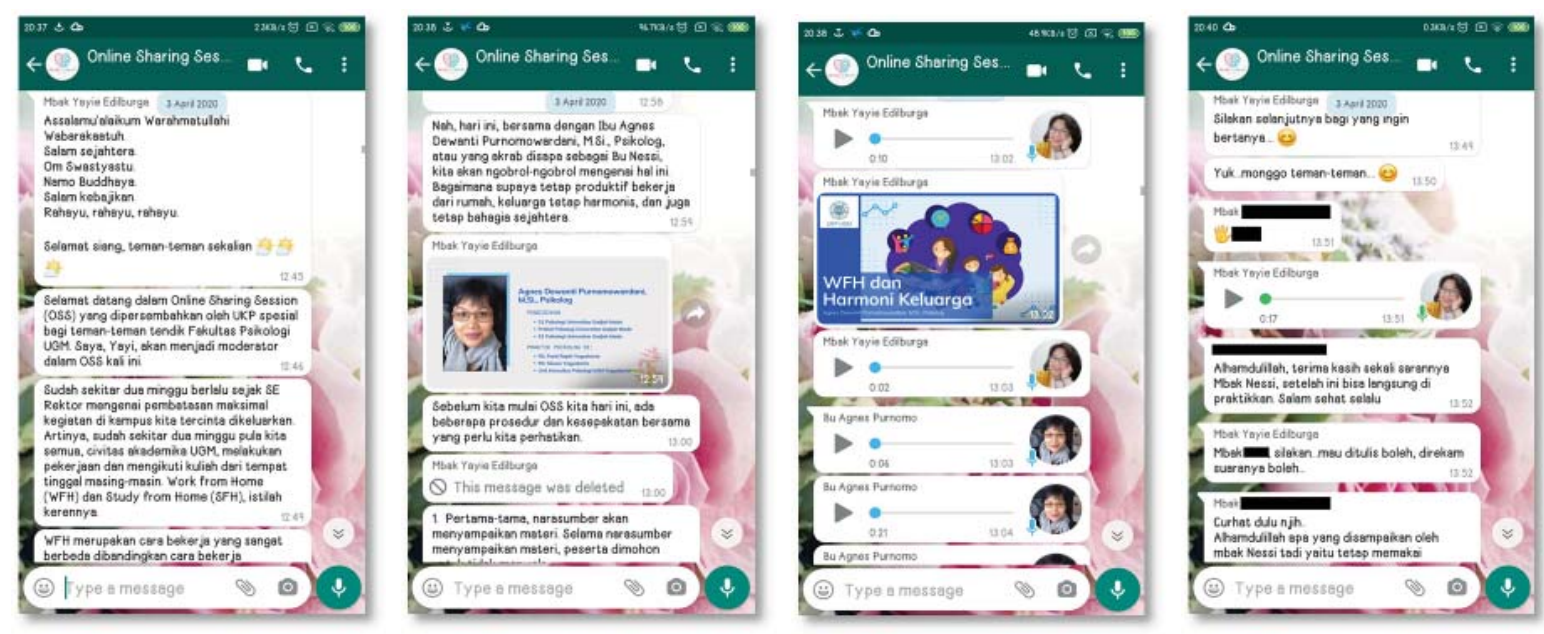

Gambar 5. Dokumentasi Kegiatan UKP Bersinergi UKP Berbagi 1

Tema UBUB ke-2 dipilih berdasarkan asesmen kebutuhan dan permasalahan atas kondisi kesehatan mental masyarakat yang mulai terganggu dikarenakan adanya berbagai informasi mengenai perkembangan COVID-19 di media sosial, pembatasan ruang, serta keharusan untuk beradaptasi terhadap perubahan yang besar karena pandemi COVID-19, tanpa diiringi kepastian kapan situasi ini akan kembali normal. Akibatnya, emosi negatif seperti cemas, insecure, dan kejenuhan mulai menguat ke permukaan. Hal tersebut mendorong program dukungan psikologis lebih diarahkan pada diskusi dan 
ABDIMAS: Jurnal Pengabdian Masyarakat Universitas Merdeka Malang

Volume 7, No 1, February 2022: 38-53

berbagi tentang cara-cara berdamai dengan emosi-emosi tersebut selama masa pandemi COVID-19. Tujuan dari program ini adalah peserta dapat mempraktikkan secara mandiri cara untuk mengelola perasaan, pikiran, dan informasi yang diterima agar menurunkan rasa cemas dan insecure, serta berdamai dengan rasa jenuh. Walaupun terdapat empat respon positif dari peserta, namun respon tersebut belum memenuhi ketercukupan untuk menyimpulkan efektivitas pemilihan topik UBUB 2. Dokumentasi kegiatan UBUB 2 berupa live Instagram dapat dilihat pada Gambar 6.

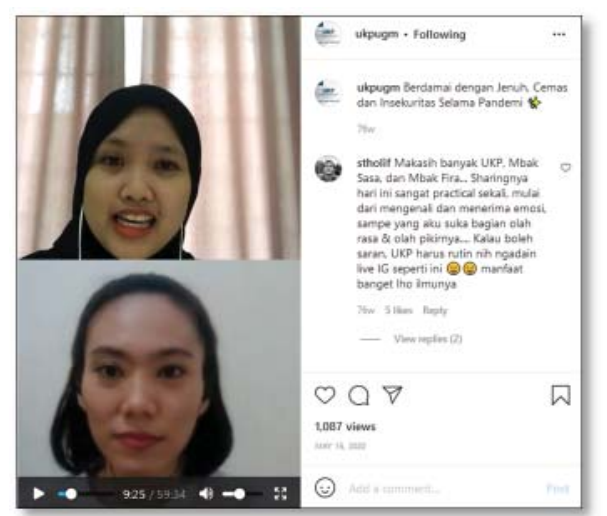

Gambar 6. Dokumentasi Kegiatan UKP Bersinergi UKP Berbagi 2

UBUB ke-3 diselenggarakan ketika masyarakat memasuki era new normal, yaitu situasi yang "memaksa" individu untuk kembali berada dalam situasi yang tidak nyaman (menjalankan semua aktivitas dengan banyak aturan dan pembatasan yang ketat). Situasi seperti ini rentan memicu munculnya luka batin pada inner child seseorang ketika menjalani masa pengasuhan (James, 1974). Pemilihan topik tentang reparenting menjadi tepat sasaran karena sebagian besar masyarakat membutuhkan proses berdamai dengan emosi negatif yang di-trigger oleh situasi selama masa pandemi COVID-19. Antusiasme dan diskusi tanpa henti mewarnai proses psikoedukasi ini. Melalui kegiatan ini (lihat Gambar 7), efektivitas dari psikoedukasi dan dukungan psikologis yang diberikan terlihat saat peserta mampu memahami emosi, serta mengaplikasikan tahapan reparenting self untuk berdamai dengan luka batin semasa inner child yang terpicu muncul kembali selama pandemi COVID-19.
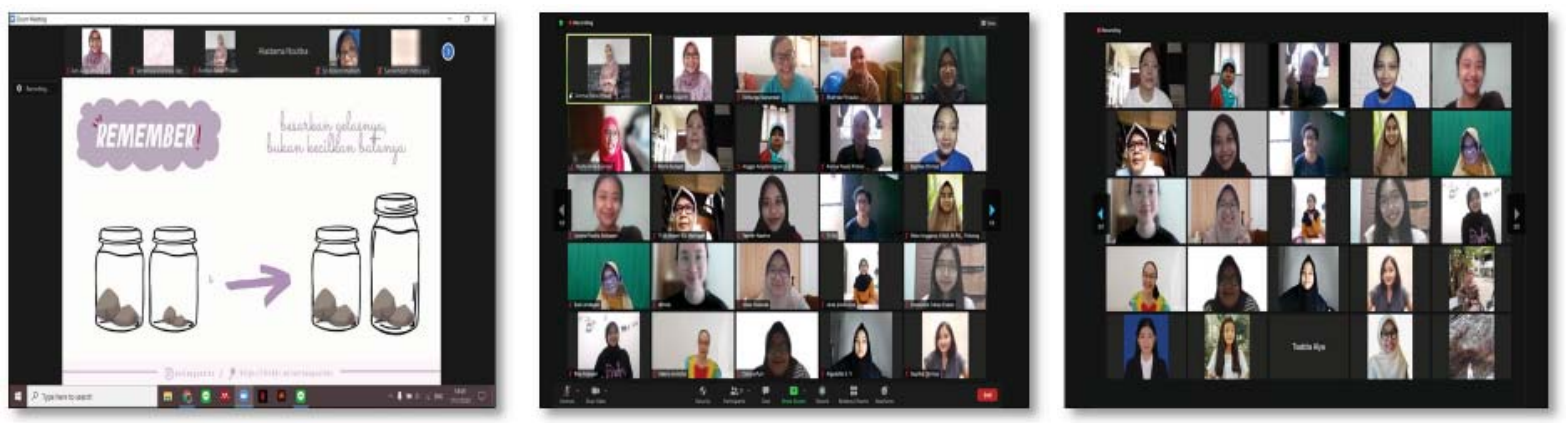

Gambar 7. Dokumentasi Kegiatan UKP Bersinergi UKP Berbagi 3

Salah satu dampak pandemi COVID-19 adalah pelaksanaan sekolah dari rumah (school from home). Adanya kebijakan pemberlakukan kembali pembatasan sosial skala besar (PSBB) dikarenakan kenaikan 
kasus terkonfirmasi positif COVID-19 pun menyebabkan kegiatan tetap harus dilaksanakan secara daring. Proses pembelajaran daring ini tentu bukan hanya membuat mahasiswa untuk menyesuaikan diri dengan perubahan metode dan memberdayakan hal-hal yang berkaitan dengan teknologi guna menunjang pembelajaran daring, namun juga terkait membangun komunikasi dan relasi sosial secara jarak jauh. Beberapa jurnal penelitian juga menemukan bahwa stres akademik yang semakin meningkat selama pembelajaran daring (school from home) berdampak pada penurunan performa mahasiswa dan kesulitan dalam penemuan strategi koping yang efektif (Lubis, Ramadhani, \& Rasyid, 2021; Wang \& Zhao, 2020; Watnaya, Muiz, Sumarni, Mansyur, \& Zaqiah, 2020; Agustiningsih, 2019). Oleh karena itu, topik tentang mengelola stres akademik di era pandemi menjadi isu penting untuk diangkat menjadi tema UBUB 4. Selain memberikan dukungan psikologis, UBUB 4 juga dapat memberikan psikoedukasi kepada mahasiswa agar lebih siap mental dalam menjalani perkuliahan berbasis daring di era pandemi COVID-19. Efektivitas kegiatan UBUB 4 ini tampak ketika mahasiswa menjadi lebih mampu memahami kondisi psikologisnya dan menemukan potensi yang ada di dalam dirinya untuk dikembangkan pasca acara. Lebih lanjut, peserta mampu menunjukkan mental yang lebih tangguh setelah menemukan insight untuk mengatasi tekanan psikologisnya, lebih semangat dalam menjalani perkuliahan, dan mampu menemukan strategi pemecahan masalah yang efektif.
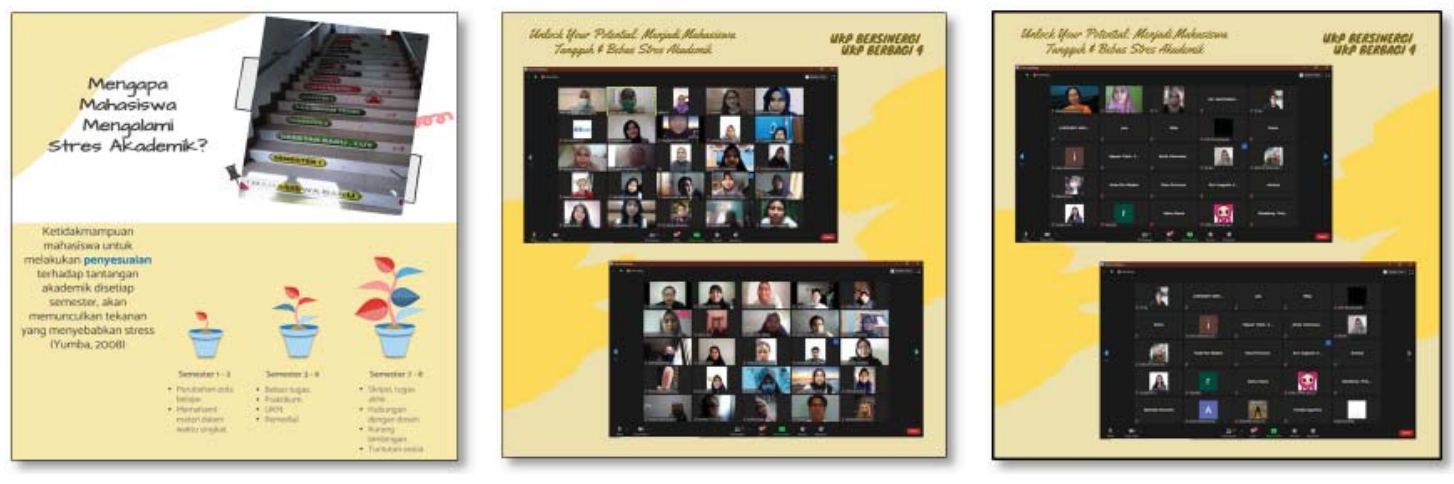

Gambar 8. Dokumentasi Kegiatan UKP Bersinergi UKP Berbagi 4

Ditinjau dari proses interaksi kelompok dikaitkan dengan media yang digunakan selama pemberian layanan psikologi, penggunaan video conference (UBUB 3 dan UBUB 4) sebagai media untuk memberikan psikoedukasi, lebih efektif dan lebih diminati dibanding dua metode lainnya. Penyampaian psikoedukasi tidak hanya dilakukan melalui teks dan audio, namun juga melibatkan interaksi langsung secara virtual sehingga peserta dapat melihat dan berkomunikasi langsung dengan narasumber. Hal tersebut diperkuat oleh hasil penelitian yang dilakukan oleh (Monica \& Fitriawati, 2020), yang menemukan bahwa proses transfer learning akan menjadi efektif saat dilakukan melalui zoom, salah satu media berbentuk video conference. Melalui media zoom, proses komunikasi dua arah terjadi secara interaktif dan mampu memotivasi peserta untuk terlibat di dalam proses kelompok. Lebih lanjut, interaksi yang terbangun di dalam kelompok ini mampu memotivasi individu yang terlibat untuk merasa dipahami dan mendapat dukungan psikologis.

Berdasarkan evaluasi dari partisipan, pemilihan media untuk melakukan layanan daring pun dianggap berpengaruh terhadap proses layanan. Beberapa partisipan menyarankan untuk lebih sering mengadakan layanan daring UBUB ini dengan menggunakan zoom cloud meeting (atau media video conference lainnya) dibanding dengan menggunakan grup whatsapp. Hal ini dikarenakan teknis pelaksanaannya dirasa lebih efektif dan membuat nyaman bagi partisipan. Pemilihan waktu kegiatan 
ABDIMAS: Jurnal Pengabdian Masyarakat Universitas Merdeka Malang

Volume 7, No 1, February 2022: 38-53

juga sebaiknya dilakukan ketika pagi atau malam agar peserta lebih bisa fokus. Durasi waktu pun menentukan efektivitas transfer knowledge dalam proses psikoedukasi tersebut. Selain itu, sebagian besar peserta menyarankan untuk tetap melanjutkan kegiatan serupa secara konsisten dan berkala, dengan tema-tema yang dekat dengan kehidupan sehari-hari dalam bentuk series, karena kegiatan ini terbukti mampu memfasilitasi kebutuhan peserta dan bermanfaat dalam menjaga kesehatan mental masyarakat. Evaluasi dan saran terkait layanan daring melalui live Instagram kurang dapat tergambarkan karena hampir tidak ada partisipan yang mengisi survei kepuasan, walaupun layanan UBUB melalui media ini dapat mencakup sasaran yang lebih luas.

Dari keempat UBUB yang telah dilaksanakan, animo yang paling tinggi muncul ketika UBUB 3 (sejumlah 48,49\% dari keseluruhan partisipan) dan UBUB 4 (43,61\% dari keseluruhan partisipan). Kuota yang dibuka pun langsung penuh terisi dalam waktu yang singkat. Selama sesi diskusi, banyak pertanyaan mengalir dari partisipan. UBUB 3 dan 4 ini juga dibuka untuk umum dan dilakukan melalui zoom cloud meeting sehingga lebih intensif dalam memfasilitasi peserta. Proses di dalam kelompok pun lebih dapat dikelola dan dimonitor. Hanya saja materi yang didiskusikan selama sesi tidak dapat disaksikan sewaktu-waktu oleh partisipan yang tidak bergabung secara sinkronus. Berbeda dengan sesi yang dilakukan melalui live Instagram, video yang membahas tema tersebut dapat disaksikan kembali sewaktu-waktu melalui IGTV Instagram UKP (hingga saat ini sudah disaksikan 1062 orang). Hanya saja proses psikoedukasi melalui live Instagram ini kurang dapat dilihat efektivitasnya karena keterbatasan dalam memberikan survei evaluasi. Oleh karena itu, psikoedukasi melalui live Instagram ini lebih difungsikan sebagai media promosi kesehatan mental.

Promosi kesehatan mental bertujuan untuk meningkatkan atau memperbaiki kapasitas koping kesehatan mental dari individu, keluarga, organisasi dan komunitas. Telah banyak dipahami bahwa makna sehat mental bukan sekedar tidak adanya gangguan atau penyakit. Terlebih, kesehatan mental berpengaruh atas kapasitas individu untuk membentuk relasi interpersonal dan sosial, berkomunikasi, berperasaan dan berpikir, koping dengan kehilangan dan perubahan, serta upaya untuk memiliki hidup yang produktif dan sejahtera (Donovan \& Anwar-McHenry, 2015). Seperti yang telah diketahui bahwa penggunaan internet dan media sosial menjadi salah satu sarana promosi kesehatan mental yang banyak digunakan terutama di tengah pandemi COVID-19.

Alasan utama penggunaan internet dan media sosial sebagai sarana penunjang UBUB atau media promosi kesehatan mental ini adalah efektivitasnya dalam penyebaran informasi. Chan et al. (2020) dalam penelitiannya mengembangkan infografis mengenai jalan napas dari pasien yang dicurgai atau dikonfirmasi COVID-19. Konten tersebut kemudian disebarkan melalui media sosial dan dalam beberapa hari mendapatkan permintaan untuk menerjemahkan konten tersebut ke lebih dari 10 bahasa. Hal ini menunjukkan bahwa informasi dapat dengan mudah disebarluaskan melalui media sosial dengan sangat cepat. Selain itu, plaftorm media sosial dapat memfasilitasi pelaksanaan proyek penelitian kolaboratif, survei online hingga studi-multi pusat di tengah pandemi COVID-19. Tak hanya itu, plaftorm media sosial juga menyediakan sumber daya yang mendukung pelaksanaan pendidikan berkelanjutan melalui web seminar atau webinar (Putri \& Prayoga, 2021). Oleh karenanya, pemilihan media Zoom dan Instagram dinilai dapat menjadi langkah yang tepat dalam pelaksanaan layanan UBUB ini, karena efektif sebagai media promosi kesehatan mental dan preventif gangguan mental. Hal ini juga dapat dibuktikan dengan jumlah peserta webinar dan viewers dari IGTV yang dinilai cukup tinggi.

Selanjutnya, dilihat dari demografi jenis kelamin partisipan, sebagian besar peserta UBUB adalah perempuan dengan persentase sebesar $88,34 \%$ dari total peserta. Perbedaaan yang cukup besar ini menunjukkan bahwa perempuan cenderung mencari dukungan sosial dalam menghadapi kesulitan 


\section{Online psychoeducation in the COVID-19 pandemic situation: an effort to improve mental health}

Edilburga Wulan Saptandari, Zafira Rahmania Nur Shabarina, Acintya Ratna Priwati

dibanding laki-laki. Hal ini didukung oleh penemuan dalam sebuah studi global yang menunjukan bahwa terdapat perbedaan gender yang sangat besar dalam keyakinan dan perilaku terkait COVID19, diketahui bahwa perempuan cenderung lebih serius dalam menanggapi pandemi COVID-19 dan menyetujui serta mematuhi peraturan pemerintah sebagai upaya pencegahan penularan (Galasso et al., 2020). Tingkat kesadaran yang tinggi itulah yang kemudian mendorong para perempuan untuk mencari informasi dan dukungan sosial serta emosional yang dibutuhkan melalui berbagai media yang tersedia salah satunya yakni layanan UBUB ini.

Apabila dilihat dari peran gender, perbedaan yang tampak disebabkan oleh adanya norma gender tradisional yang masih dianut dalam masyarakat, yaitu perempuan merasa memiliki kerentanan yang lebih dibanding sebelum pandemi, sedangkan laki-laki merasa harus bisa lebih kuat dari sebelumnya. Pernyataan ini sejalan dengan penelitian sebelumnya yang telah menemukan bahwa ketika pandemi COVID-19 terjadi, perempuan diasosiasikan dengan kerentanan yang lebih besar terhadap stres, gangguan stres pasca trauma (PTSD) dan depresi (Xiong et al., 2020). Selain itu, perempuan juga menunjukan prevalensi yang lebih besar untuk merasakan kecemasan dan depresi (Salari et al., 2020). Perbedaan berdasarkan jenis kelamin ini juga ditunjukan pada saat sebelum terjadi pandemi yakni perempuan memiliki tingkat psychological distress yang lebih tinggi daripada laki-laki (Auerbach et al., 2018). Penelitian-penelitian tersebut menunjukan bahwa perempuan pada dasarnya memiliki tingkat kerentanan yang lebih rendah sehingga mereka kemudian berupaya lebih keras untuk meningkatkan kesadaran dan manajemen diri untuk menghadapi pandemi COVID-19.

Pengguna layanan daring UBUB ini sebagian besar tinggal di Pulau Jawa $(87,5 \%$ dari keseluruhan partisipan) dan sisanya berasal dari luar Pulau Jawa. 12.5\% partisipan dari luar Pulau Jawa ini menunjukkan bahwa salah satu keuntungan adanya layanan daring, yaitu dapat dihadiri dan dijangkau oleh masyarakat di luar Pulau Jawa yang sangat membutuhkan layanan ini tanpa harus datang ke Yogyakarta. Kemajuan teknologi telah membawa kemudahan bagi penyelenggara dalam melaksanakan layanan kesehatan mental gratis. Kehadiran layanan webinar daring yang bisa diakses dari mana saja merupakan suatu langkah yang efektif, terutama di tengah pandemi COVID-19 seperti saat ini karena dapat meminimalisir risiko tatap muka. Selain itu, manfaat lain dari kemajuan teknologi yakni dapat menjadi media edukasi untuk memberikan pengetahuan tentang perawatan dan manajemen kesehatan mental yang proaktif terkait COVID-19 (Putri \& Prayoga, 2021).

Survei kepuasan terkait layanan daring UBUB yang diadakan oleh UKP selama masa pandemi COVID-19 menunjukkan bahwa sebagian besar partisipan menyatakan puas dengan layanan daring UKP, dengan hasil perolehan survei $20.61 \%$ dari total partisipan memberikan rating $10,35.88 \%$ memberikan rating 9,33.59\% memberikan rating $8,6.87 \%$ memberikan rating 7, 0.76\% memberikan rating 6 , dan $2.29 \%$ memberikan rating di bawah 5. Partisipan yang memberikan rating di atas 5 menilai layanan daring UBUB ini memberikan fasilitas dalam memperkuat kondisi psikologisnya ketika menghadapi isu serupa di masa pandemi ini, ditambah dengan tema yang diangkat menarik dan disajikan oleh narasumber dengan cara yang membangkitkan semangat partisipan. Partisipan yang menilai di bawah 5 merasa adanya keterbatasan waktu interaksi antara pembicara dan peserta sehingga masih ada beberapa pertanyaan partisipan yang belum bisa terjawab di sesi diskusi.

Dalam survei yang diberikan, 96,95\% partisipan merasa bahwa harapannya dalam mengikuti kegiatan UBUB dapat tercapai. Harapan tersebut antara lain adalah memeroleh pengetahuan, insight, dan saran/masukan seputar kondisi yang sedang dihadapi. Selain itu, partisipan juga berharap mendapatkan dukungan emosional, serta lebih mengenal dirinya sendiri dengan memahami, memotivasi, dan mencintai diri sendiri di tengah situasi pandemi. Sementara itu, 3,05\% partisipan menyatakan bahwa harapannya 
ABDIMAS: Jurnal Pengabdian Masyarakat Universitas Merdeka Malang

Volume 7, No 1, February 2022: 38-53

belum tercapai karena merasa materi yang dibawakan bersifat umum sehingga kurang mendapatkan langkah praktis untuk diterapkan. Kegiatan UBUB ini meninggalkan beberapa kesan yang disampaikan oleh partisipan. Topik yang menarik dan sangat dekat dengan keseharian membuat partisipan mudah untuk memahami materi yang disampaikan. Hal ini juga didukung oleh penyampaian narasumber yang dikemas dengan sederhana dan interaktif. Dari kegiatan ini, partisipan juga merasa mendapatkan wawasan baru. Selain kesan positif yang diberikan, terdapat beberapa partisipan yang menyampaikan tidak dapat mengikuti sesi dengan baik karena adanya kendala sinyal dari perangkat yang dimiliki.

\section{SIMPULAN DAN SARAN}

Data yang didapatkan dari empat kegiatan UBUB yang telah dilakukan menunjukkan bahwa layanan daring selama masa pandemi COVID-19 turut memfasilitasi masyarakat dalam menjaga kesehatan mentalnya, terutama saat layanan tersebut sifatnya gratis serta topik atau tema yang diangkat relevan dengan isu yang sedang dialami. Antusiasme masyarakat terhadap layanan tersebut juga ditunjukkan melalui sesi diskusi yang memfasilitasi peserta untuk bertanya dan mendiskusikan materi secara lebih mendalam dengan pemateri. Kemajuan teknologi juga memudahkan penyebaran informasi mengenai kegiatan UBUB sehingga dalam waktu singkat kuota langsung terpenuhi dan dapat mencakup audiens yang lebih luas dengan karakteristik yang lebih beragam. Hanya saja durasi UBUB dirasa terlalu singkat dan membatasi waktu interaksi antara pembicara dengan peserta, terlebih saat masih ada pertanyaanpertanyaan dari peserta yang belum dapat dijawab atau didiskusikan. Faktor penghambat lainnya selama pelaksanaan UBUB adalah tipe psikoedukasi dalam level medium seperti menggunakan live Instagram akan menimbulkan kesulitan untuk mengetahui efektivitasnya karena peserta bebas keluar dan masuk dalam diskusi. Walaupun layanan ini memiliki keuntungan yakni video materinya dapat disaksikan kembali sewaktu-waktu terutama bagi peserta yang tidak dapat bergabung secara sinkronus. Selain itu, jumlah partisipan yang mengisi survei juga tidak mencapai setengah dari total partisipan.

Terdapat beberapa saran yang dapat ditawarkan untuk pelaksanaan UBUB selanjutnya yakni mengadakan UBUB dalam bentuk series dan mengadakan sesi yang lebih privat untuk memfasilitasi peserta agar dapat berproses lebih dalam. Untuk mendukung hal tersebut, tema yang dipilih dalam kegiatan UBUB selanjutnya juga dapat mempertimbangkan karakteristik dan demografi partisipan, misalnya dengan menyelenggarakan series khusus untuk remaja, perempuan, atau pasangan yang sudah menikah. Selain itu, pengadaan UBUB secara berkala dan rutin dengan mengangkat tema yang ditemukan pada layanan konsultasi gratis UKP dipandang sebagai kegiatan yang relevan dengan konteks. Pelaksanaan UBUB juga perlu mempertimbangkan penggunaan media berbagi, seperti Zoom/ Google Meeting atau platform sejenisnya. Selanjutnya, media sosial Instagram dapat digunakan sebagai promosi kesehatan mental, misalnya dengan cara menyusun poster sederhana yang berisi rangkuman singkat mengenai materi UBUB yang dilaksanakan melalui Zoom/Google Meeting. Publikasi dari kegiatan ini juga perlu diperluas, supaya dapat menjangkau masyarakat Indonesia secara menyeluruh. Terakhir, pengisian survei dapat menjadi syarat yang harus dipenuhi sebelum melakukan transfer e-money pada partisipan.

\section{UCAPAN TERIMA KASIH}

Penulis mengucapkan terima kasih kepada Fakultas Psikologi UGM, seluruh narasumber, moderator, dan peserta yang terlibat dalam kegiatan psikoedukasi dan penelitian ini. 


\section{DAFTAR PUSTAKA}

Agustiningsih, N. (2019). Gambaran stres akademik dan strategi koping pada mahasiswa keperawatan. Jurnal Ners dan Kebidanan (Journal of Ners and Midwifery), 6 (2), 241-250. https://doi.org/10.26699/jnk.v6i2.art.p241-250

Auerbach, R. P., Alonso, J., Axinn, W. G., Cuijpers, P., Ebert, D. D., Green, J. G., Hwang, I., Kessler, R. C., Liu, H., Mortier, P., Nock, M. K., Pinder-Amaker, S., Sampson, N. A., Aguilar-Gaxiola, S., AlHamzawi, A., Andrade, L. H., Benjet, C., Caldas-De-Almeida, J. M., Demyttenaere, K., ... Bruffaerts, R. (2016). Mental disorders among college students in the World Health Organization World Mental Health Surveys. Psychological Medicine, 46(14), 2955-2970. https://doi.org/10.1017/S0033291716001665

Berryman, C., Ferguson, C. J., \& Negy, C. (2018). Social media use and mental health among young adults. Psychiatric Quarterly, 89(2), 307-314. https://doi.org/10.1007/s11126-017-9535-6

Carver, P., \& Phillips, J. (2020). Novel Coronavirus (COVID-19): What you need to know. Workplace Health \& Safety, 250.

Chan, A. K. M., Nickson, C. P., Rudolph, J. W., Lee, A., \& Joynt, G. M. (2020). Social media for rapid knowledge dissemination: Early experience from the COVID-19 pandemic. Anaesthesia, 75(12), 1579-1582. https://doi.org/10.1111/anae.15057

Chan, A., \& Huak, C. Y. (2014). Psychological impact of the 2003 severe acute respiratory syndrome outbreak on health care workers in a medium size regional general hospital in Singapore. Occupational Medicine, 54(3), 190-196. https://doi.org/10.1093/occmed/kqh027

Crosbie, T. \& Moore, J. (2004). Work-life balance and working from home. Social Policy and Society, 3 (3). 223-233. https://doi.org/10.1017/S1474746404001733

Donovan, R.J., Anwar-McHenry, J. (2015). Promoting mental health and wellbeing in individuals and communities: the 'Act-Belong-Commit' campaign. In: Wymer W. (eds). Innovations in social marketing and public health communication. Applying quality of life research (best practices). Springer, Cham. https://doi.org/10.1007/978-3-319-19869-9_11

Galasso, V., Pons, V., Profeta, P., Becher, M., Brouard, S., \& Foucault, M. (2020). Gender differences in COVID-19 attitudes and behavior: Panel evidence from eight countries. Proceedings of the National Academy of Sciences of the United States of America, 117(44), 27285-27291. https://doi.org/10.1073/pnas.2012520117

Gugus Tugas Percepatan Penanganan COVID-19. (2020). Pedoman penanganan cepat medis dan kesehatan masyarakat COVID-19 di Indonesia. Jakarta: Badan Nasional Penanggulangan Bencana.

Hammad, M. A., \& Alqarni, T. M. (2021). Psychosocial effects of social media on the Saudi society during the Coronavirus Disease 2019 pandemic: A cross-sectional study. PLoS ONE, 16 (3 March), 1-13. https://doi.org/10.1371/journal.pone.0248811

James, M. (1974). Reparenting: Theory and process. Journal of Transactional Analysis, 4(3), 32-39. https://doi.org/10.1177/036215377400400307

Kang, L., Li, Y., Hu, S., Chen, M., Yang, C., Yang, B. X., Wang, Y., Hu, J., Lai, J., Ma, X., Chen, J., Guan, L., Wang, G., Ma, H., \& Liu, Z. (2020). The mental health of medical workers in Wuhan, China dealing with the 2019 novel coronavirus. The Lancet Psychiatry, 7(3), e14.

https://doi.org/10.1016/S2215-0366(20)30047-X 
ABDIMAS: Jurnal Pengabdian Masyarakat Universitas Merdeka Malang Volume 7, No 1, February 2022: 38-53

Kementerian Kesehatan Republik Indonesia. (2020, April 19). Situasi terkini perkembangan COVID-19. Diakses pada April 19, 2020, dari Infeksi Emerging.

Lai, D., Wang, D., Calvano, J., Raja, A. S., \& He, S. (2020). Addressing immediate public coronavirus (COVID-19) concerns through social media: Utilizing Reddit's AMA as a framework for public engagement with science. PLoS ONE, 15(10 October), 1-11.

https://doi.org/10.1371/journal.pone.0240326

Lee, S. M., Kang, W. S., Cho, A.-R., Kim, T., \& Park, J. K. (2018). Psychological impact of the 2015 MERS outbreak on hospital workers and quarantined hemodialysis patients. Comprehensive Psychiatry, 123-127. https://doi.org/10.1016/j.comppsych.2018.10.003

Lubis, H., Ramadhani, A., \& Rasyid, M. (2021). Stres akademik mahasiswa dalam melaksanakan kuliah daring selama masa pandemi COVID-19. Psikostudia: Jurnal Psikologi, 10 (1), 31-39. https://doi.org/10.30872/psikostudia

Monica, J., \& Fitriawati, D. (2020). Efektivitas penggunaan aplikasi zoom sebagai media pembelajaran online pada mahasiswa saat pandemi COVID-19. Jurnal Communio: Jurnal Komunikasi, IX(2), 1630-1640. https://doi.org/10.35508/jikom.v9i2.2416

Presiden Republik Indonesia. (2020). Keputusan Presiden Republik Indonesia Nomor 11 Tahun 2020 tentang Penetapan Kedaruratan Kesehatan Masyarakat Corona Virus Disease 2019 (COVID-19). $031003,1-2$.

Presiden Republik Indonesia. (2020). Peraturan Pemerintah Nomor 21 Tahun 2020 tentang Pembatasan Sosial Berskala Besar Dalam Rangka Percepatan Penanganan Coronavirus Disease 2019/COVID19. 2019(022868), 8.

Putri, A., \& Prayoga, D. (2021). Pemasaran sosial menggunakan media sosial dalam upaya pencegahan penularan COVID-19: tinjauan literatur. E-journal Undip, 144-149.

Salari, N., Hosseinian-Far, A., Jalali, R., Vaisi-Raygani, A., Rasoulpoor, S., Mohammadi, M., Rasoulpoor, S., \& Khaledi-Paveh, B. (2020). äÇïÑì. Globalization and Health, 16(1), 1-11.

Srivatsa, S., \& Stewart, K. (2020). How should clinicians integrate mental health into epidemic responses? AMA Journal of Ethics, 22(1), 10-15. https://doi.org/10.1001/amajethics.2020.10.

Taylor, S. (2019). The psychology of pandemics: Preparing for the next global outbreak of infectious disease. Newcastle upon Tyne: Cambridge Scholars Publishing.

Torales, J., O'Higgins, M., Castaldelli-Maia, J. M., \& Ventriglio, A. (2020). The outbreak of COVID-19 coronavirus and its impact on global mental health. International Journal of Social Psychiatry, 1-4. https://doi.org/10.1177/0020764020915212

Wang, C., \& Zhao, H. (2020). The impact of COVID-19 on anxiety in Chinese University students. Frontiers in Psychology, 11, 1168. https://doi.org/10.3389/fpsyg.2020.01168

Wang, C., Pan, R., Wan, X., Tan, Y., Xu, L., Ho, C., \& Ho, R. (2020). Immediate psychological responses and associated factors during the initial stage of the 2019 Coronavirus Disease (COVID-19) epidemic among the general population in China. International Journal of Environmental Research and Public Health, 1-25. https://doi.org/10.1177/0020764020915212

Wang, Y., Zhao, X., Feng, Q., Liu, L., Yao, Y., \& Shi, J. (2020). Psychological assistance during the coronavirus disease 2019 outbreak in China. Journal of Health Psychology, 1-5.

https://doi.org/10.1177/1359105320919177 
Online psychoeducation in the COVID-19 pandemic situation: an effort to improve mental health Edilburga Wulan Saptandari, Zafira Rahmania Nur Shabarina, Acintya Ratna Priwati

Watnaya, A. K., Muiz, M. H., Sumarni, N., Mansyur, A. S., \& Zaqiah, Q. Y. (2020). Pengaruh teknologi pembelajaran kuliah online di era COVID-19 dan dampaknya terhadap mental mahasiswa. EDduTeach: Jurnal Edukasi dan Teknologi Pembelajaran, 1 (2), 153-165.

https://doi.org/10.37859/eduteach.v1i2.1987

World Health Organization. (2020). World Health Organization. Diakses pada Maret 18, 2020, dari Rolling updates on coronavirus diseas (COVID-19).

Xiong, J., Lipsitz, O., Nasri, F., Lui, L. M. W., Gill, H., Phan, L., Chen-Li, D., lacobucci, M., Ho, R., Majeed, A., \& McIntyre, R. S. (2020). Impact of COVID-19 pandemic on mental health in the general population: A systematic review. Journal of Affective Disorders, 277(August), 55-64. https://doi.org/10.1016/j.jad.2020.08.001 